\title{
Satisfaction of Women in Fulfilling the Role as Mothers - A Comparative Study between Working and Nonworking Mothers
}

\author{
Louis Manohar ${ }^{1}$

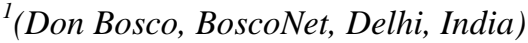 \\ Corresponding Author: Louis Manohar
}

\begin{abstract}
Women's role in the community and at home have been changing rapidly. Traditionally, men and women had well-defined roles without much overlapping or trespassing- mostly women were confined to home - their primary was 'mother' and 'care-taker'. But, women's rights, education, and gender equality has changed the scenario. Pursuance of quality life, better living standard, cost of living has compelled women to become economic contributors of the home. However, not much significant changes have been observed in gender roles. The question is whether women are satisfied about their role as mother or care-taker. The objective of the study is to explore the difference in the perceived satisfaction in fulfilling the role as a mother and satisfaction in life between working mothers and non-working mothers. Results indicated significant differences between working and nonworking mothers. Nonworking mothers were comparatively more satisfied being able to fulfil their motherly role. Within the working mothers, type of occupation significantly affects their satisfaction outcomes. However, marital status had no impact on the satisfaction outcomes.
\end{abstract}

Keywords: Women, Life satisfaction, Mother, Employed women, Mother's role

Date of Submission: 07-09-2019

Date of Acceptance: 23-09-2019

\section{INTRODUCTION}

Traditionally, men and women in a family shared different roles without much overlapping of roles [1] - men were considered as breadwinners, providers of physical protection, and were mostly active outside the house; whereas, women played the role of caregivers, taking care of the family members, doing the household chores, and mostly confined within the house. Mothers generally engage in personal care, companionship, moral, and spiritual development of children [2]. But now gender roles are changing. Women's education, gender equality and equity measures have expanded the spheres of activity for women.

Despite the changing gender roles, workingwomen, in reality, have to play at least two major roles, viz., the domestic role of homemaker at home, and the employee role at the workplace. Workingwomen are subjected to confrontation with a number of barriers and conflicting situations at workplaces, at home, and in the society. Compared to nonworking women, workingwomen are vulnerable to higher level of stress due to their multiple roles. For example, nonworking women have more time to attend the household chores, such as taking care of the children and family members, and thus are in a more advantageous position than workingwomen, in fulfilling their role as mothers, at home.

Parents', particularly mother's dissatisfaction, affects children's holistic development. There would be less strain in relationships between satisfied parents. Strained relationship affects the satisfaction in life.

In such a family, children enjoy a productive and familial environment, which would contribute towards the development of skill, good culture, and behaviour among the children.

People feel happy, when they are in a position to fulfil their role up to their perceived standards and satisfaction. Role-satisfaction would result in a synergistic effect in improving relations between the parents, as well as between the parents and the children. When a person is dissatisfied with the quality of role he/she has been performing, may become prone to stress. Prolonged stress condition, inadvertently, leads to psychological and physical health problems. Perceptibly, one may form the opinion that nonworking women might have more satisfaction in fulfilling their role as the female head of the family, at home, but the outcomes of numerous studies are equally divided on this aspect. "Life satisfaction is one of the major components of subjective wellbeing concept. [3]

However, one of the indicators of women empowerment is women's economic independence; and employment makes women economically independent - if not in full, at least to some extent. In marriages, workingwomen are more preferred, since income from a single person will not be adequate for a family to fulfil 
the modern-day requirements, cost of living, and to enjoy the comforts of the present-day life. In this context, the study aims to explore the life satisfaction of working and nonworking women.

\section{STATEMENT OF THE PROBLEM}

Young working mothers, particularly, with very young children, and who head the families, have more family responsibilities. Mothers perceive that their responsibility within the family is more compared to men [4]. In fact, sociologists argue that women are now in a position to play multiple roles. This definitely has impacts on their physical and psychological health, availability of time for the household chores.

\section{REVIEW OF LITERATURE}

A number of studies have found that workingwomen are happier, have better physical health and more satisfied than compared to homemakers [5] [6]. Ferrer-i-Carbonell \& Frijters (2004) found that satisfied and happy working mothers are more productive [7]. However, Wright (1976) did not find any evidence to show a difference in the level of life satisfaction between working and nonworking women [8].

Farel, 1980; Hock \& DeMeis, 1990 found that full-time mothers expressed dissatisfaction over their role as full-time homemakers and indicated preference for employment [9] [10]. The attempt to discharge the multiple roles viz. a mother, spouse and employee, largely results in role conflict [11] and lower level of satisfaction and psychological wellbeing [12]. Jones et al, (2007) demonstrated a positive association between women's status and child wellbeing [13].

Several studies have focused on the mother's role satisfaction as a full-time homemaker or as a working mother [14] [15] and the quality of child-mother relationship [16].

Women's role in their home and society has changed towards more participation, sharing of responsibilities and decision making [17]. Holahan and Gilbert (1979) found conflict between the three roles, viz. as a worker, spouse, and mother, among working mothers [18].

\section{OBJECTIVES OF THIS STUDY}

1. To explore the life satisfaction among mothers.

2. To examine how the three satisfaction outcomes, viz. life satisfaction, personal wellbeing, role satisfaction, differ between working and nonworking mothers.

3. To study the influence of employment status on the role satisfaction (as mothers) among working mothers.

\section{Participants}

\section{METHODS AND MEASURES}

Participants in this study were both working and nonworking married women with children. Samples were from four northern districts and four southern districts of Tamil Nadu State, India. A total of 720 mothers (528 working and 192 nonworking mothers) and equal number of respondents from each of the eight districts were selected. A structured questionnaire was used to collect data. Questionnaires were served to the subjects through NGO volunteers in the respective districts.

\section{Questionnaire}

Data were collected using a well-structured close-end self-reporting questionnaire. Satisfaction with life was measured using the Satisfaction with Life Scale developed by Diener et al. (1985) [19]. The scale contained five statements and scores ranged from 1 (strongly disagree) to 7 (strongly agree). Higher scores mean higher satisfaction. Satisfaction in personal wellbeing was measured using the Personal Wellbeing Index - Adult (PWI-A) scale developed by The International Wellbeing Group (2006) [20]. The scale measures "standard of living, personal health, achieving in life, personal relationships, personal safety, communityconnectedness, future security, and spirituality or religion" using eleven-point scoring method ranging from $0=$ "No satisfaction at all" to $10=$ "Completely satisfied". Self-developed construct was used to measure the mother's role satisfaction. The construct contained 11 items measured over a seven-point scale ranging from 1 $=$ Not at all satisfied to $7=$ Extremely satisfied. Higher score means higher satisfaction in fulfilling the mother's role. Other personal variables, viz. age, education, profession, marital status, No. of children, type of family, and employment status of spouse were also included.

\section{RESULTS AND DISCUSSIONS}

Participants' were only married women in the age group of 28 to 40 years. The average age of the participants was $34.67( \pm 3.630)$ years. Participants' education level ranged from Higher Secondary to M.Phil/PhD. Majority of the women participants were UG or PGs (73.3\%). M.Phil/PhD and professional degree holders were 6.7 per cent. The remaining women were educated up to Higher Secondary level or below $(13.3 \%)$. Average monthly income of those women who were employed ranged from $\langle$ Rs.20,001 to $>$ 
Rs.40,000. Majority of the participants' income was between Rs.20,001 and Rs.40,000 per month. Absolute majority of the respondents were living with their husband (98.8\%) and most of them had only two children, and living in nuclear family system $(60.0 \%)$.

Table No 1: Role preference and actual occupation status

\begin{tabular}{|ll|c|c|c|c|c|}
\hline & & \multicolumn{3}{|c|}{ Actual Occupation Status } & Total \\
\cline { 3 - 7 } & & $\begin{array}{c}\text { Homemaker } \\
\text { (Not } \\
\text { employed) }\end{array}$ & $\begin{array}{c}\text { Clerical/Supe } \\
\text { rvising/Frontl } \\
\text { ine job }\end{array}$ & Teacher & Professional & \\
\hline Preferred \\
Role & To be a Fulltime & 0 & 96 & 192 & 0 & 288 \\
& 'Homemaker' & $0.0 \%$ & $33.3 \%$ & $66.7 \%$ & $0.0 \%$ & $100.0 \%$ \\
\cline { 2 - 7 } & To be 'Employed' & 192 & 96 & 96 & 48 & 432 \\
& $44.4 \%$ & $22.2 \%$ & $22.2 \%$ & $11.1 \%$ & $100.0 \%$ \\
\hline Total & 192 & 192 & 288 & 48 & 720 \\
& $26.7 \%$ & $26.7 \%$ & $40.0 \%$ & $6.7 \%$ & $100.0 \%$ \\
\hline
\end{tabular}

The above table shows interesting results. Women who wished to be a fulltime 'homemaker' were employed, and about 44.4 per cent of the women who wished to be 'employed' were fulltime homemakers. About one-fourth $(26.7 \%)$ of the participants were fulltime homemakers (not employed), others were employed as office/frontline staffs $(26.7 \%)$, teachers $(40.0 \%)$, and professionals $(6.7 \%)$. Sixty per cent of the participants preferred to be employed rather than being just a 'homemaker'.

Table No 2: Role preference and satisfaction outcomes

\begin{tabular}{|l|l|c|r|r|r|c|c|}
\hline \multirow{2}{*}{ DV } & Role & $\mathrm{N}$ & \multicolumn{2}{|c|}{ DV Scores } & \multicolumn{3}{|c|}{$t$-test Statistics } \\
\cline { 5 - 8 } & Preference & $(720)$ & Mean & SD & $t$ & df & $p$ \\
\hline Overall satisfaction & Homemaker & 288 & 7.467 & 1.1254 & 6.982 & 718 & .000 \\
with life & Employed & 432 & 6.756 & 1.4639 & & & \\
\hline \multirow{2}{*}{ Personal wellbeing } & Homemaker & 288 & 6.933 & 1.2967 & -.107 & 718 & .915 \\
& Employed & 432 & 6.944 & 1.3082 & & & \\
\hline \multirow{2}{*}{ Role satisfaction } & Homemaker & 288 & 8.467 & .9689 & 4.526 & 718 & .000 \\
& Employed & 432 & 8.096 & 1.1423 & & & \\
\hline
\end{tabular}

Significant differences were observed in the overall satisfaction with life and role-satisfaction mean scores between the role-preference groups. Women who preferred to be a 'homemaker' were significantly better satisfied with life $[\mathrm{t}(718)=7.467, p<.001]$ as well as in their role as 'mothers' $[\mathrm{t}(718)=8.467, p<.001]$. However, there was no significant difference in the personal wellbeing scores between women who preferred to be a homemaker and to be employed groups.

Table No 3: Present occupation and satisfaction outcomes

\begin{tabular}{|l|l|c|c|c|c|c|c|}
\hline \multirow{2}{*}{ DV } & Present & $\mathrm{N}$ & \multicolumn{2}{c|}{ DV Scores } & \multicolumn{2}{c|}{ ANOVA Test Statistics } \\
\cline { 4 - 8 } & Occupation & $(720)$ & Mean & SD & df & $F$ & Sig. \\
\hline \multirow{3}{*}{ Overall satisfaction } & Not employed & 192 & 7.200 & .8237 & 3 & 109.852 & .000 \\
with life & Frontline job & 192 & 7.850 & .4512 & 716 & & \\
& Teacher & 288 & 6.800 & 1.6409 & & & \\
& Professional & 48 & 4.600 & .0000 & & & \\
\hline \multirow{5}{*}{ Personal wellbeing } & Not employed & 192 & 7.199 & .8892 & 3 & 236.876 & .000 \\
& Frontline job & 192 & 6.699 & 1.3487 & 716 & & \\
& Teacher & 288 & 7.467 & .6300 & & & \\
& Professional & 48 & 3.700 & .0206 & & & \\
\hline \multirow{5}{*}{ Role satisfaction } & Not employed & 192 & 8.450 & .7942 & 3 & 124.565 & .000 \\
& Frontline job & 192 & 8.475 & .9062 & 716 & & \\
& Teacher & 288 & 8.350 & .9946 & & & \\
& Professional & 48 & 5.865 & .1376 & & & \\
\hline
\end{tabular}




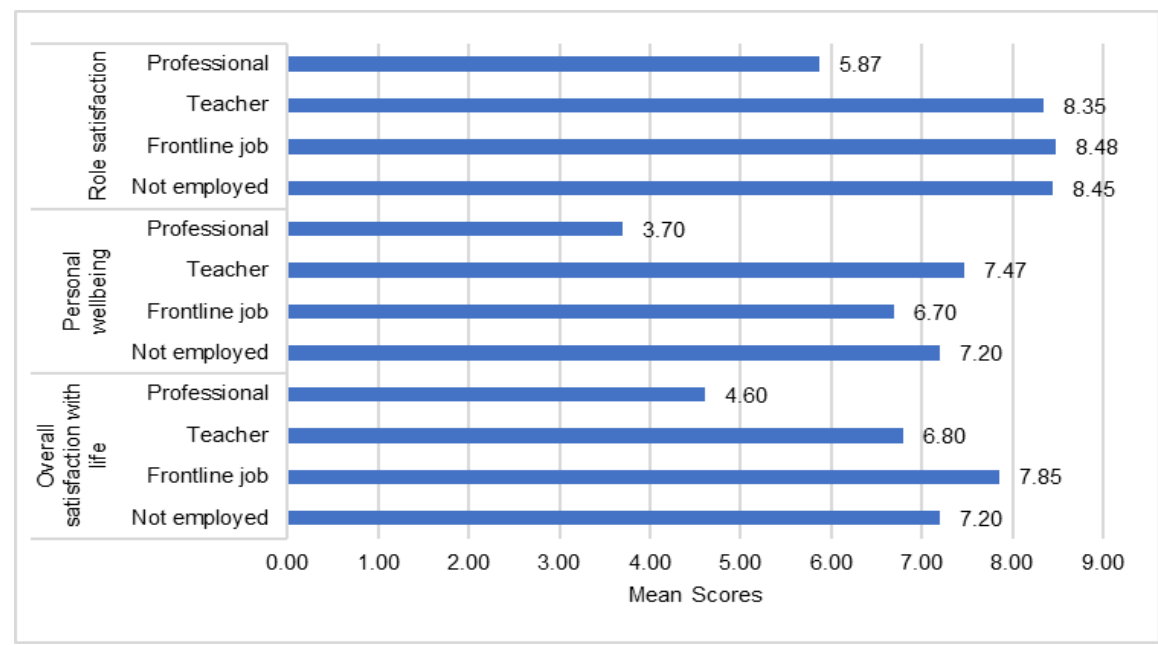

Fig 1: Occupation vs. satisfaction outcome

Overall life satisfaction, personal wellbeing, and role-satisfaction men scores significantly differed between the working and non-working mothers - significant at 0.001 level. Mean scores were higher for all the three satisfaction variables for the 'not employed' group. Post-hoc test revealed that, within the working women groups, mean scores of overall satisfaction with life $[\mathrm{F}(3,716)=4.600, p<.001]$, personal wellbeing $[\mathrm{F}(3,716)=3.700, p<.001]$, and role satisfaction $([\mathrm{F}(3,76)=5.865, p<.001]$ were significantly lower (at .001 level) for the 'professional' group, compared to women in other professions.

Table No 4: Table No : Marital status and satisfaction outcomes

\begin{tabular}{|c|c|c|c|c|c|c|}
\hline \multirow[t]{2}{*}{ DV } & \multirow[t]{2}{*}{ Marital Status } & \multirow{2}{*}{$\begin{array}{c}\mathrm{N} \\
(720)\end{array}$} & \multirow[t]{2}{*}{ Mean Rank } & \multicolumn{3}{|c|}{$\begin{array}{c}\text { Kruskal-Wallis Test } \\
\text { Statistics }\end{array}$} \\
\hline & & & & $\chi^{2}$ & $\mathrm{df}$ & Sig. \\
\hline $\begin{array}{l}\text { Overall } \\
\text { satisfaction } \\
\text { with life }\end{array}$ & $\begin{array}{l}\text { Married \& living with husband } \\
\text { Divorced / separated } \\
\text { widow }\end{array}$ & $\begin{array}{c}711 \\
4 \\
5\end{array}$ & $\begin{array}{l}362.12 \\
252.50 \\
216.50\end{array}$ & 3.598 & 2 & .165 \\
\hline $\begin{array}{l}\text { Personal } \\
\text { wellbeing }\end{array}$ & $\begin{array}{l}\text { Married \& living with husband } \\
\text { Divorced / separated } \\
\text { Widow }\end{array}$ & $\begin{array}{c}711 \\
4 \\
5 \\
\end{array}$ & $\begin{array}{l}361.27 \\
222.88 \\
360.50 \\
\end{array}$ & 1.785 & 2 & .410 \\
\hline $\begin{array}{l}\text { Role } \\
\text { satisfaction }\end{array}$ & $\begin{array}{l}\text { Married \& living with husband } \\
\text { Divorced / separated } \\
\text { Widow }\end{array}$ & $\begin{array}{c}711 \\
4 \\
5\end{array}$ & $\begin{array}{l}361.38 \\
288.50 \\
293.30\end{array}$ & 1.020 & 2 & .600 \\
\hline
\end{tabular}

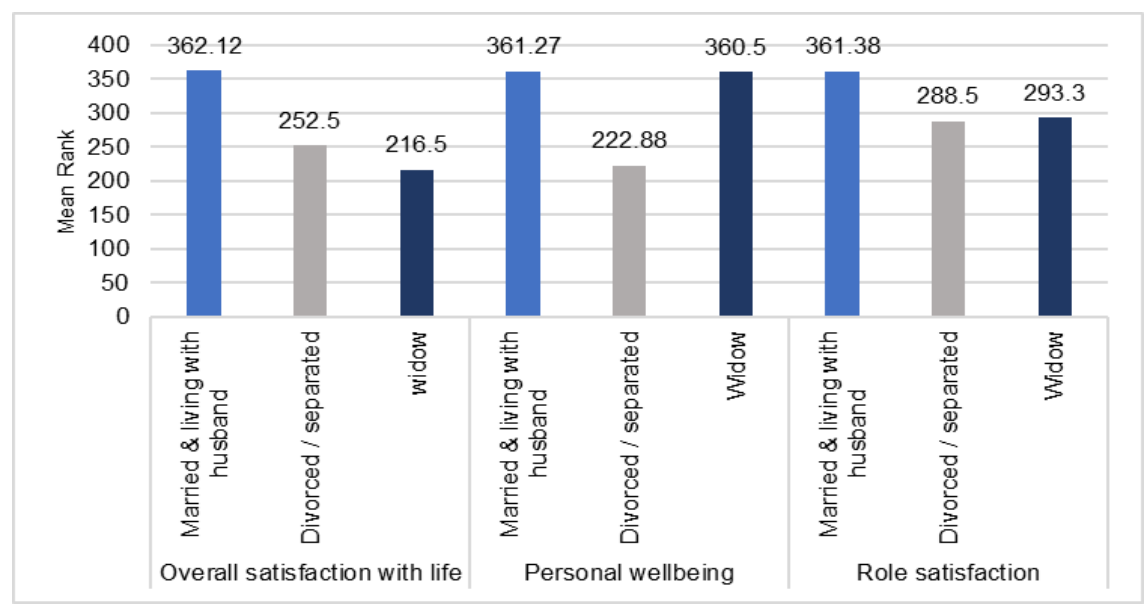

Fig 2: Marital status and satisfaction outcomes

Kruskal-Wallis test did not reveal any statistically significant differences in the mean scores of overall satisfaction with life, personal wellbeing, and role satisfaction between the three marital status groups compared $(p>.05)$. However, marginal differences were observed. For example, 'married \& living with husband' group 
indicates marginally higher scores of overall satisfaction (362.12), personal wellbeing (361.27), and role satisfaction (361.38) compared to the other two groups.

Table No 5:Type of family and satisfaction outcomes

\begin{tabular}{|c|c|c|c|c|c|c|c|}
\hline \multirow{2}{*}{ DV } & \multirow{2}{*}{$\begin{array}{l}\text { Type of } \\
\text { Family }\end{array}$} & \multirow{2}{*}{$\begin{array}{c}\mathrm{N} \\
(720)\end{array}$} & \multicolumn{2}{|c|}{ DV Scores } & \multicolumn{3}{|c|}{$t$-test Statistics } \\
\hline & & & Mean & SD & $t$ & df & $p$ \\
\hline Overall & Nuclear & 432 & 7.383 & 1.3777 & 5.552 & 718 & .000 \\
\hline $\begin{array}{l}\text { satisfaction } \\
\text { with life }\end{array}$ & Joint & 288 & 6.811 & 1.3394 & & & \\
\hline Personal & Nuclear & 432 & 7.083 & 1.5524 & 2.423 & 718 & .016 \\
\hline wellbeing & Joint & 288 & 6.844 & 1.0970 & & & \\
\hline Role & Nuclear & 432 & 8.377 & 1.3305 & 2.685 & 718 & .007 \\
\hline satisfaction & Joint & 288 & 8.156 & .8869 & & & \\
\hline
\end{tabular}

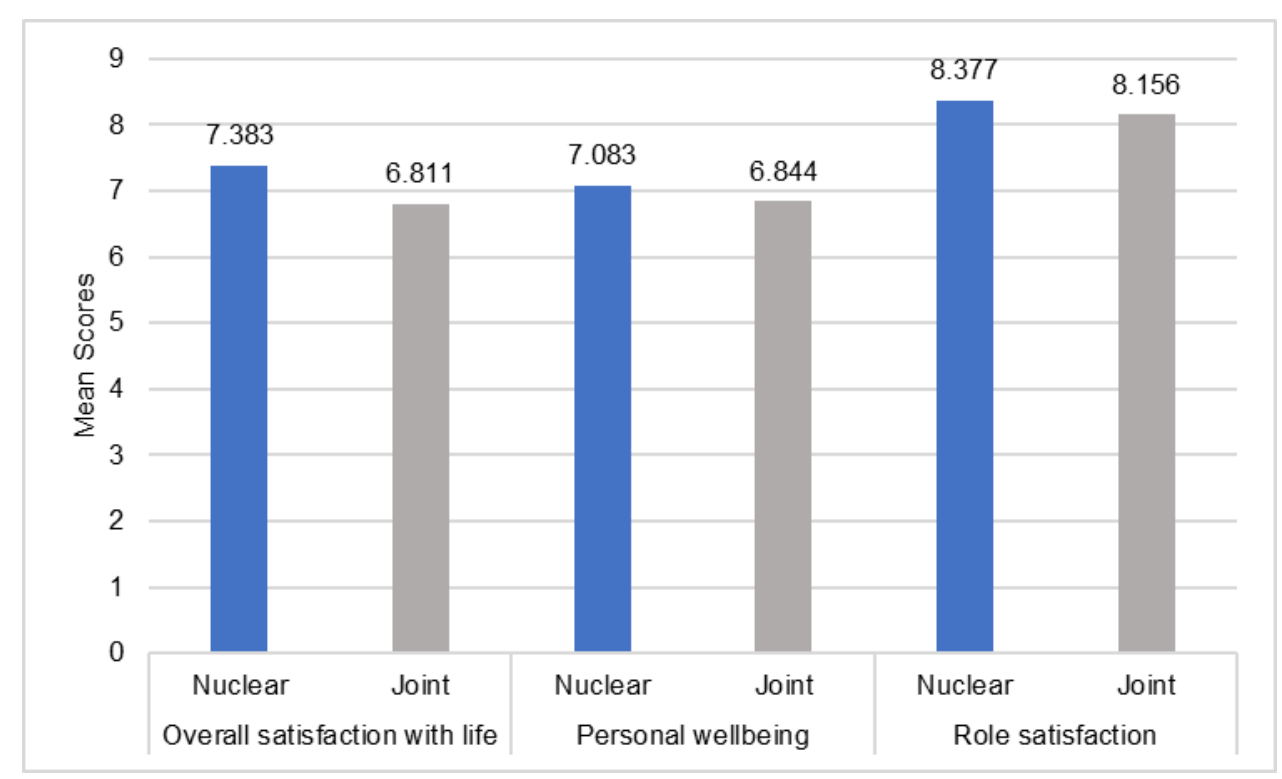

Fig 3: Type of family and satisfaction outcomes

Significant differences in the mean scores of the three satisfaction outcomes were indicated between the nuclear and joint family groups. Mothers in nuclear family set up were significantly more satisfied with life $[\mathrm{t}(718)=7.383, p<.001]$, better personal wellbeing $[\mathrm{t}(718)=7.083, p<.05]$, and satisfaction in fulfilling their role as mothers $[\mathrm{t}(718)=8.377, p<.05]$, compared to mothers in the joint family system.

Table No 6: Age vs. outcome variables

\begin{tabular}{|l|l|r|r|r|}
\hline \multicolumn{2}{|l|}{ Variables } & $\begin{array}{c}\text { Overall } \\
\text { Satisfaction } \\
\text { with Life }\end{array}$ & $\begin{array}{c}\text { Overall } \\
\text { Personal } \\
\text { Wellbeing }\end{array}$ & $\begin{array}{c}\text { Overall Role } \\
\text { Satisfaction }\end{array}$ \\
\hline Age & Pearson Correlation & $.200^{* *}$ & $-.267^{* *}$ & $.436^{* *}$ \\
& Sig. (2-tailed) & .000 & .000 & .000 \\
\hline
\end{tabular}

$\mathrm{N}=720$

Pearson's correlation test shows highly significant correlation between age and the mean scores of satisfaction with life, personal wellbeing, and role satisfaction. Positive correlation between age and overall satisfaction, and age and overall role satisfaction were indicated. Comparatively stronger and positive correlation was observed between age and role satisfaction $(r=.436 p<.001)$, about 19.0 percent of variations in the role satisfaction mean scores was associated with the variance in age. Mean scores of personal wellbeing were inversely associated with age $(r=-.267 \mathrm{p}<.001)$. 
Table No 7: Intercorrelation between satisfaction outcome variables

\begin{tabular}{|c|c|c|c|c|}
\hline \multicolumn{2}{|c|}{ Variables } & $\begin{array}{c}\text { Overall Satisfaction } \\
\text { with Life }\end{array}$ & $\begin{array}{l}\text { Overall Personal } \\
\text { Wellbeing }\end{array}$ & $\begin{array}{l}\text { Overall Role } \\
\text { Satisfaction }\end{array}$ \\
\hline $\begin{array}{l}\text { Overall Satisfaction } \\
\text { with Life }\end{array}$ & $\begin{array}{l}\text { Pearson Correlation } \\
\text { Sig. (2-tailed) }\end{array}$ & 1 & & \\
\hline $\begin{array}{l}\text { Overall Personal } \\
\text { Wellbeing }\end{array}$ & $\begin{array}{l}\text { Pearson Correlation } \\
\text { Sig. (2-tailed) }\end{array}$ & $\begin{array}{r}.389^{* *} \\
.000\end{array}$ & 1 & \\
\hline $\begin{array}{l}\text { Overall Role } \\
\text { Satisfaction }\end{array}$ & $\begin{array}{l}\text { Pearson Correlation } \\
\text { Sig. (2-tailed) }\end{array}$ & $\begin{array}{r}.511^{* *} \\
.000\end{array}$ & $\begin{array}{r}.657^{* *} \\
.000\end{array}$ & 1 \\
\hline
\end{tabular}

$\mathrm{N}=720$

Pearsons' correlation test revealed significant (at 0.001 level) and positive inter-correlation between the mean scores of life satisfaction, personal wellbeing, and role-satisfaction. Mean score of satisfaction in role and personal wellbeing were more strongly associated. About $43.16 \%$ of variation in the personal wellbeing mean scores were explained by the variations in the mean scores of overall role satisfaction. Weak but significant association was indicated between the mean scores of personal well wellbeing and overall satisfaction in life $(r$ $=.389, p<.001)$.

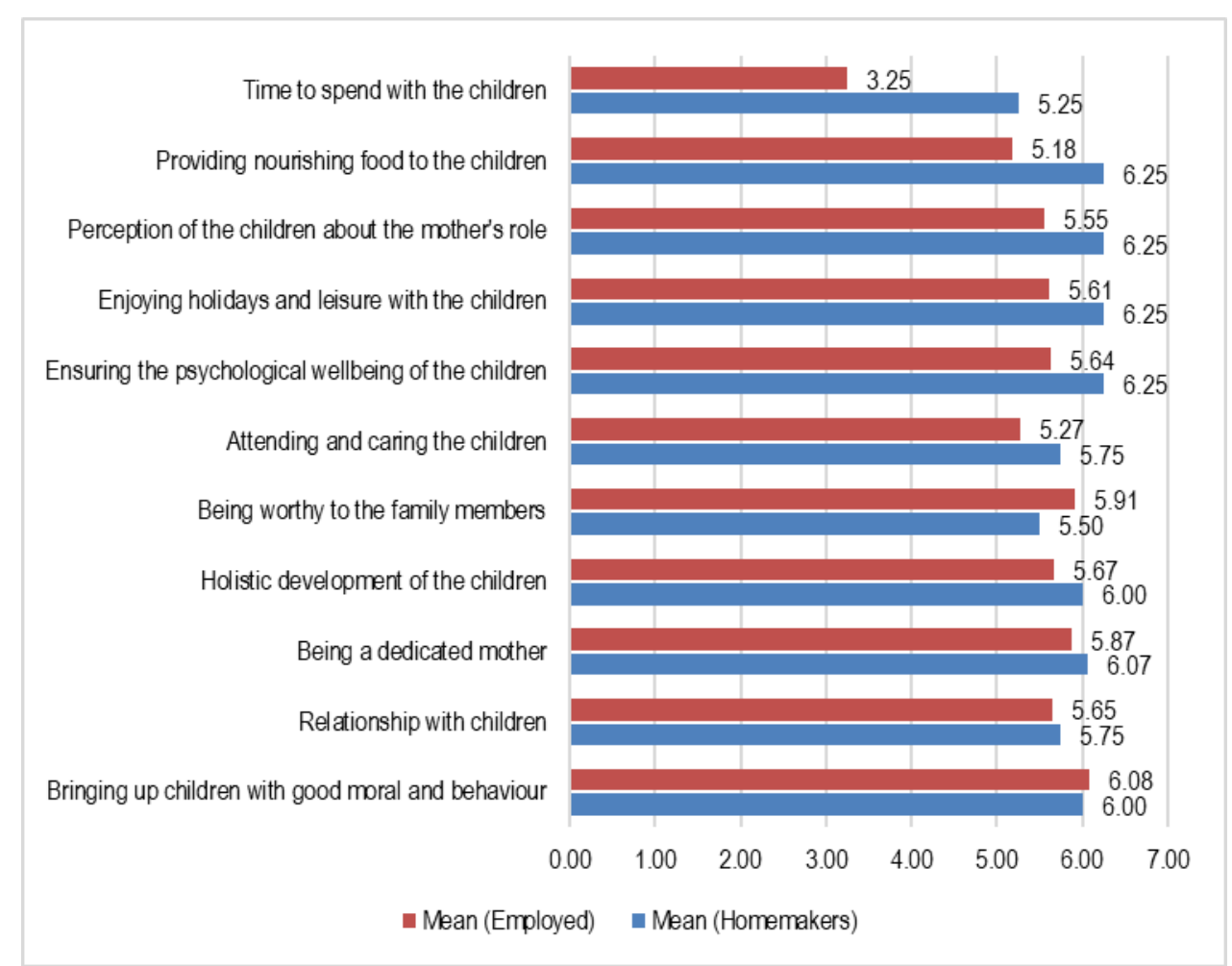

Fig 4: Occupation status vs. individual satisfaction outcomes

Figure No.4 shows the comparison of mean scores of satisfaction in fulfilling the role as mothers between working and nonworking mothers. The indicators are arranged in the order of difference. Satisfaction in time to spend with their children was very low among the employed mothers. Also, satisfaction in providing nourishing food to the children, perceived children's opinion about their mother's role, enjoying leisure with the children, ensuring psychological wellbeing of their children were also much low among the employed mothers, compared to the nonworking mothers. Satisfaction in relationship with their children and in bringing up their children with good moral and behavior were almost same.

\section{DISCUSSION \& CONCLUSION:}

Results indicated significant differences in the three satisfaction outcomes between working women and nonworking women. Initially, which role women preferred was explored. Interestingly women who preferred to be a fulltime homemaker have ended up as employed and about half of those who preferred to be employed were currently fulltime homemakers. May be this is due to the attraction about the opposite status. Type of occupation had a significant impact on the mothers' satisfaction outcomes. For example, women who were working as professionals, were less satisfied about their overall life satisfaction, personal wellbeing, and 
role satisfaction. Mostly, working mothers were less satisfied and more concerned about the lack of time to spend with their children. Overall life satisfaction and role satisfaction were better among women who were in frontline jobs. Teachers' perceived better personal wellbeing, compared to the other two occupational groups. Marital status of women did not have any significant impact on their satisfaction outcomes. Family system significantly affected women's satisfaction outcomes. For example, women in a nuclear family system were more satisfied about their overall life, personal wellbeing, and being able to fulfil their role as mothers. Age was also a significant factor. With increase in age, overall satisfaction with life and role satisfaction also increased. However, older women perceived lower levels of personal wellbeing compared to younger women and vice versa. The three satisfaction outcomes were mutually and positively associated. This means that satisfaction with life, personal wellbeing, and role satisfaction mutually improves each other.

Hence, it is concluded that fulltime women homemakers (i.e. nonworking women) are more satisfied about their overall life and particularly, to fulfil their duties as a mother. Younger women were more satisfied, compared to older women. Nature of job affects women's ability to discharge their duties as mothers and also affects their personal wellbeing and overall satisfaction. Women prefer nuclear family system. Overall satisfaction in life, personal wellbeing, and ability to fulfil their role as mothers impacts each other positively

\section{REFERENCES}

[1]. Craig, L. (2006). Does father care mean fathers share? A comparison of how mothers and fathers in intact families spend time with children. Gender and Society, 20, 259-281. doi:10.1177/0891243205285212.

[2]. Finley, G.E., Mira, S.D. and Schwartz, S.J. (2008). Perceived paternal and maternal involvement: Factor structures. Mean differences and parental roles. Fathering, 6(1), 62-82. doi:10.3149/fth.0601.62.

[3]. Pavot, W. \& Diener, E. (1993). Review of the satisfaction with life scale. Psychological Assessment, 5, 164-172.

[4]. Gerstel N, and Sarkisian N. (2006). Sociological perspectives on families and work: The import of gender, class and race. In: Pitt-Catsouphes, M., Kossek, E. and Sweet, S. (Eds.) (2006). The work and family handbook: multidisciplinary perspectives, methods and approaches. Boston: Lawrence Earlbaum, 237-266.

[5]. Ferree, M. (1976). Working class jobs: Housework and paid work as sources of satisfaction. Social Problems, 23, 431-441.

[6]. Coleman, L.M. \& Antonucci, T.C. (1976). Impact of work on women. Departmental Psychology, 19(2), 290-294.

[7]. Ferrer-i-Carbonell, A. \& Frijters, P. (2004). How important is methodology for the estimates of the determinants of happiness? The Economic Journal, 114(497), 641-659.

[8]. Wright, D. (1978). Are working women really more satisfied: Evidence from several National Surveys. Journal of Marriage and Family, 40, 301-313.

[9]. Farel, A. M. (1980). Effects of preferred maternal roles, maternal employment, and sociodemographic status on school adjustment and competence. Child Development, 51(4), 1179-1186.

[10]. Hock, E., \& DeMeis, D. K. (1990). Depression in mothers of infants: The role of maternal employment. Developmental Psychology, 26(2), 285-291.

[11]. Buffardi, L. C., \& Erdwins, C. J. (1997). Child-care satisfaction: linkages to work attitudes, interrole conflict, and maternal separation anxiety. Journal of Occupational Health Psychology, 2(1), 84-96.

[12]. Noor, N.M. (2003). Work- and family-related variables, work-family conflict and women's well-being: some observations. Community, Work and Family, 6(3), 297-315.

[13]. Jones, N, Mukherjee, M, \& Galab, S. (2007), "Ripple Effects or Deliberate Intentions? Assessing Linkages between Women's Empowerment and Childhood Poverty", paper presented at the international seminar on Member Based Organizations of the poor, CESS, June 2007.

[14]. Hock, E., \& DeMeis, D. K. (1990). Depression in mothers of infants: The role of maternal employment. Developmental Psychology, 26(2), 285-291.

[15]. Ross, M.E. and Ross, C.L. Mothers, infants, and the psychoanalytic study of ritual. Journal of Women in Culture and Society, 9(1), 26-45

[16]. Stuckey, M. F., McGhee, P. E., \& Bell, N. J. (1982). Parent-child interaction: The influence of maternal employment. Developmental Psychology, 18(4), 635-644.

[17]. Goleman, D. (1998). Working with emotional intelligence. New York: Bantam Books.

[18]. Holahan, C.K. and Gilbert, L.A. (1979). Interrole conflict for working women: Careers versus jobs. Journal of Applied Psychology, 64(1), 86-90. http://dx.doi.org/10.1037/0021-9010.64.1.86.

[19]. Diener, E., Emmons, R.A., Larsen, R.J., and Griffin, S. (1985). The satisfaction with life scale. Journal of Personality Assessment, 49, 71-75.

[20]. International Wellbeing Group. (2006). Personal Wellbeing Index (4th ed.). Melbourne: Australian Centre on Quality of Life, Deakin University. 